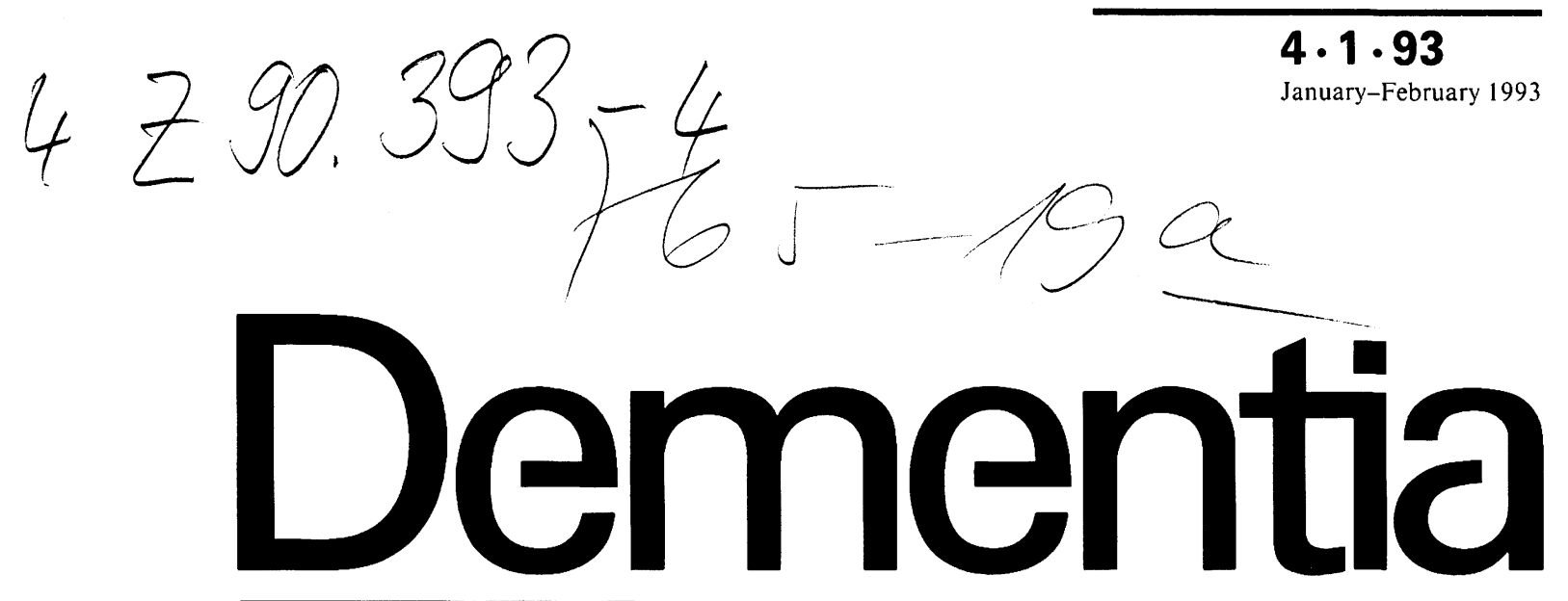

\section{S. Karger}

Medical and Scientific Publishers

Basel · Freiburg

Paris · London

New York - New Delhi

Bangkok - Singapore

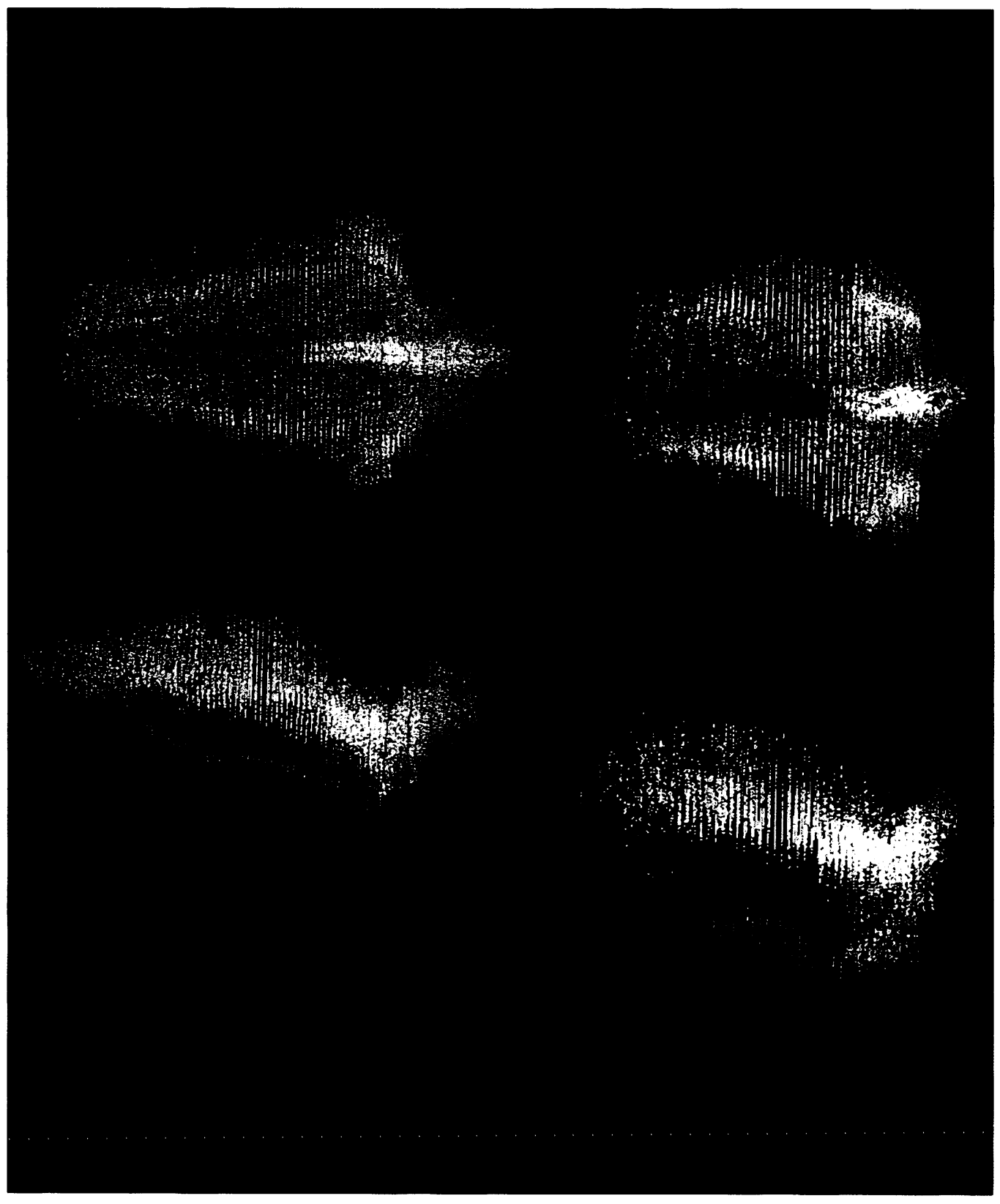

KARGER

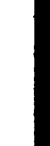

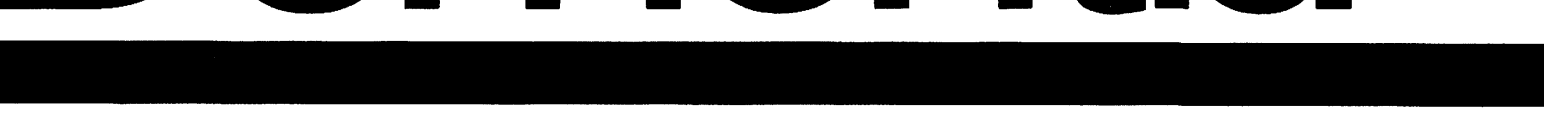




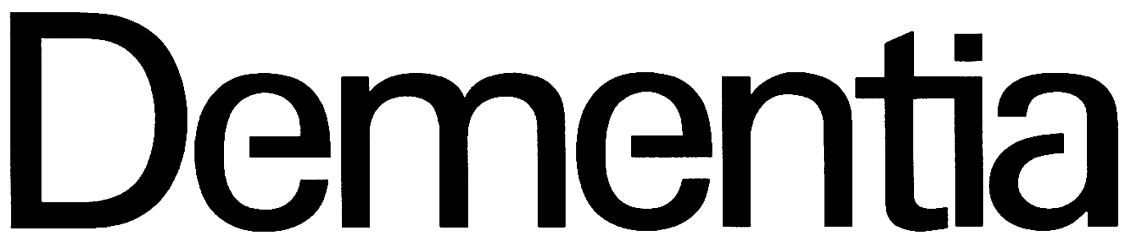

\section{Editor-in-Chief}

V. Chan-Palay, New York, N.Y.

\section{Editorial Board}

L. Amaducci, Florence

M.J. Ball, Portland, Oreg.

K. Beyreuter, Heidelberg

D.M. Bowen, London

A. Brun, Lund

S.H. Ferris, New York, N.Y.

D.C. Gajdusek, Bethesda, Md.

C.G. Gottfries, Gothenburg

L. Gustafson, Lund

K. Hasegawa, Kawasaki

F.F. Hefti, Los Angeles, Calif.

A.S. Henderson, Canberra

S. Hirai, Gummaken

F. Javoy-Agid, Paris

A.D. Korczyn, Tel Aviv
C.L. Masters, Melbourne

R. Mayeux, New York, N.Y.

E. Melamed, Petah-Tiqva

D.L. Murphy, Bethesda, Md.

D.S. Olton, Baltimore, Md.

E.K. Perry, Newcastle upon Tyne

J.W. Pettegrew, Pittsburgh, Pa.

D. Price, Baltimore, Md.

J. Rogers, Sun City, Ariz.

A.D. Roses, Durham, N.C.

M. Roth, Cambridge

Y. Sakaki, Fukuokashi

H.M. Wisniewski,

Staten Island, N.Y.

M. Yoshida, Tochigi 


\section{No. 1}

\section{Original Research Articles}

Calbindin D-28k and Monoamine Oxidase A Immunoreactive Neurons in the Nucleus Basalis of Meynert in Senile Dementia of the Alzheimer Type and Parkinson's Disease

Chan-Palay, V.; Höchli, M.; Savaskan, E.; Hungerecker, G.

The Spatial Patterns of Plaques and Tangles in Alzheimer's Disease Do Not Support the 'Cascade Hypothesis'

Armstrong, R.A.; Myers, D.; Smith, C.U.M.

Brain Damage Caused by Ischemia: Pathophysiological and Pharmacological Aspects

Rami, A.; Krieglstein, J.

Oral Tetrahydroaminoacridine Treatment of Alzheimer's Dis- 32 ease Evaluated Clinically and by Regional Cerebral Blood Flow and EEG

Minthon, L.; Gustafson, L.; Dalfelt, G.; Hagberg, B.; Nilsson, K.;

Risberg, J.; Rosén, I.; Seiving, B.; Wendt, P.E.

Multichannel EEG Frequency Analysis and Somatosensory-

Evoked Potentials in Patients with Different Types of Organic

Dementia

Rosén, I.; Gustafson, L.; Risberg, J.

Increased Sweat Sodium Concentration in Patients with

Alzheimer's Disease

Elmståhl, S.; Winge, L.

Psychometric Discrimination of Tetrahydroaminoacridine

Responders in Alzheimer Patients

Alhainen, K.; Helkala, E.-L.; Riekkinen, P.

\section{(.............................................................. \\ tter to the Editor}

Clinical Course and CSF Amyloid $\beta$ Protein Precursor Having the Site of Application of the Protease Inhibitor (APPI) Levels in Patients with Dementia of the Alzheimer Type

Urakami, K.; Takahashi, K.; Okada, A.; Oshima, T.; Adachi, Y.; Nakamura, S.; Kitaguchi, N.; Tokushima, Y.; Yamamoto, S.; Tanaka, S.

\section{No. 2}

\section{Original Research Articles}

Distribution of Iron in the Basal Ganglia and Neocortex in

Postmortem Tissue in Parkinson's Disease and Alzheimer's

Disease

Griffiths, P.D.; Crossman, A.R.

Quantitative Assessment of the Synaptophysin Immuno-Reactivity of the Cortical Neuropil in Various Neurodegenerative Disorders with Dementia

Zhan, S.-S.; Beyreuther, K.; Schmitt, H.P.

Rare Neuropil Threads in Amyotrophic Lateral Sclerosis and 75 Parkinsonism-Dementia on Guam and in the Kii Peninsula of Japan

Wakayama, I.; Kihira, T.; Yoshida, S.; Garruto, R.M.

Reduced Phosphatidylinositol Kinase Activity in Alzheimer's

Disease: Effects of Age and Onset

Jolles, J.; Bothmer, J.; Markerink, M.; Ravid, R.

43 Assessment of Depression in Alzheimer's Disease: Symptoms, 87 Syndrome, and Computed Tomography Findings

Troisi, A.; Pasini, A.; Gori, G.; Sorbi, T.; Biagini, C.; Aulisi, A.; Baroni, A.; Ciani, N.

50 Pattern of Cerebral Metabolic Interactions in a Subject with Isolated Amnesia at Risk for Alzheimer's Disease:

A Longitudinal Evaluation

Pietrini, P.; Azari, N.P.; Grady, C.L.; Salerno, J.A.; Gonzales-Aviles, A.; Heston, L.L.; Pettigrew, K.D.; Horwitz, B.; Haxby, J.V.; Schapiro, M.B.

Is Impaired Recall in Dementia of the Alzheimer Type a Con- 102 sequence of a Contextual Retrieval Deficit?

Pollmann, S.; Haupt, M.; Romero, B.; Kurz, A.

59 Long-Term Effects of Bilateral Frontal Lobe Lesions from

Neuropsychiatric and Neuroradiological Aspects

Hakola, H.P.A.; Puranen, M.; Repo, L.; Tiihonen, J.

Delirium in the Elderly: Relationship of Clinical Symptoms to 113 Outcome

Wada, Y.; Yamaguchi, N.

Telephone-Assessed Mental State

Lanska, D.J.; Schmitt, F.A.; Stewart, J.M.; Howe, J.N.

Letter to the Editor

MRI Findings in an Individual at Risk for Familial 120

Alzheimer's Disease

Ball, J.A.; Kennedy, A.M.; Roques, P.; Stevens, J.; Rossor, M.N. 
No. 3-4

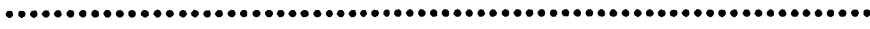

The 2nd International Conference on Frontal Lobe Degeneration of Non-Alzheimer Type

September 11-12, 1992, Lund, Sweden

Guest Editor: Arne Brun, Lund

Editorial: Dementia of Frontal Type

Brun, A.

Frontal Lobe Degeneration of Non-Alzheimer Type Revisited 126

Brun, A.

Overview of Dementia Lacking Distinctive Histology:

Pathological Designation of a Progressive Dementia

Knopman, D.S.

Presenile Dementia with Motor Neuron Disease

Mitsuyama Y.

Clinical Picture of Frontal Lobe Degeneration of

Non-Alzheimer Type

Gustafson, L.

Progressive Frontal Dysfunction

Benson, D.F.

The Clinical Pathological Correlates of Lobar Atrophy

Neary, D.; Snowden, J.S.; Mann, D.M.A.

Spectrum of Frontal Lobe Dementia in a Swedish Family

Passant, U.; Gustafson, L.; Brun, A.

Exclusion Mapping in Familial Non-Specific Dementia

Brown, J.; Gydesen, S.; Sorensen, S.A.: Brun, A.; Duff, K.; Houlden, H.;

Fidani, L.; Kullkarni, S.; Cummings, J.; Goate, A.; Rossor, M.; Hardy, J.

Neuropeptides in Cerebrospinal Fluid of Patients with

Alzheimer's Disease and Dementia with Frontotemporal

Lobe Degeneration

Edvinsson, L.; Minthon, L.; Ekman, R.; Gustafson, L.

Preliminary Neurochemical Findings in Non-Alzheimer

Dementia due to Lobar Atrophy

Francis, P.T.; Holmes, C.; Webster, M.-T.; Stratmann, G.C.;

Procter, A.W.; Bowen, D.M.

Prion Diseases in Humans and Their Relevance to Other

Neurodegenerative Diseases

Collinge, J.: Palmer, M.S.

Regional Cerebral Blood Flow in Frontal Lobe Dementia of

\section{Non-Alzheimer Type}

Risberg, J.; Passant, U.; Warkentin, S.; Gustafson, L.

Functional Activation of the Frontal Lobes. Regional Cerebral 188 Blood Flow Findings in Normals and in Patients with Frontal Lobe Dementia Performing a Word Fluency Test

Warkentin. S.: Passant, U.

Functional Imaging, the Frontal Lobes, and Dementia 192

Friedland, R.P.: Koss, E.: Lerner, A.; Hedera, P.; Ellis, W.; Dronkers, N.; Ober, B.A.; Jagust, W.J.
Progressive Right Frontotemporal Degeneration:

Clinical, Neuropsychological and SPECT Characteristics

Miller, B.L.; Chang, L., Mena, I.; Boone, K.; Lesser, I.M.

Neuropsychological Findings in Frontal Lobe Dementia

Elfgren, C.; Passant, U.; Risberg, J.

Assessment of Neuropsychological Dysfunction in Frontal

Lobe Degeneration

Stuss, D.T.

Progressive Language Dysfunction and Lobar Atrophy

Snowden, J.S.; Neary, D.

Frontal Lobe Cognitive Functions in Aging: Methodologic

232

Considerations

Brauer Boone, K.; Miller, B.L.; Lesser, I.M.

No. 5

Original Research Articles

Galaninergic Innervation of the Cholinergic Vertical Limb of the Diagonal Band (Ch2) and Bed Nucleus of the Stria terminalis in Aging, Alzheimer's Disease and Down's Syndrome Mufson, E.J.; Cochran, E.; Benzing, W.; Kordower, J.H.

The Ratio of Diffuse to Mature Beta/A4 Deposits in 251 Alzheimer's Disease Varies in Cases with and without

Pronounced Congophilic Angiopathy

Armstrong, R.A.; Myers, D.; Smith, C.U.M.

Phosphorylation of Tau by Cyclic-AMP-Dependent Protein

Kinase

Robertson, J.; Loviny, T.L.F.; Goedert, M.; Jakes, R.; Murray, K.J.;

Anderton, B.H.; Hanger, D.P.

Dendritic Atrophy and Remodeling of Amygdaloid Neurons in 264 Alzheimer's Disease

Scott, S.A.

Induction of Memory and Cortical Cholinergic Neurochemical 273

Recovery with Combine Fetal Transplantation and GM1

Treatments in Rats with Lesions of the NBM

Santucci, A.C.; Gluck, R.; Kanof, P.D.; Haroutunian, V.

Variation in Psychiatric and Behavioural Symptoms at Differ- 282 ent Stages of Dementia: Data from Physicians' Examinations and Informants' Reports

Forsell, Y.; Jorm, A.F.; Winblad, B.

Influence of Feelings of Burden on the Caregiver's Perception 287 of the Patient's Functional Status

Mangone, C.A.; Sanguinetti, R.M.; Baumann, P.D.; Gonzalez, R.C.;

Pereyra, S.; Bozzola, F.G.; Gorelick, P.B.; Sica, R.E.P.

A Comparison of Cognitive Impairments in Dementia of the

294

Alzheimer Type and Depression in the Elderly

Geffen, G.; Bate, A.; Wright, M.; Rozenbilds, U.; Geffen, L. 
No. 6

\section{Original Research Articles}

APP Expression in Primary Neuronal Cell Cultures from P6 301 Mice during in vitro Differentiation

Dichgans, M.; Mönning, U.; König, G.; Sandbrink, R.; Masters, C.L.; Beyreuther, K.

Heparan Sulfate Expression Patterns in the Amyloid Deposits 308 of Patients with Alzheimer's and Lewy Body Type Dementia Van Gool, D.; David, G.; Lammens, M.; Baro, F.; Dom, R.

Growth Hormone Secretion in Alzheimer's Disease: Studies 315 with Growth Hormone-Releasing Hormone Alone and Combined with Pyridostigmine or Arginine

Ghigo, E.; Nicolosi, M.; Arvat, E.; Marcone, A.; Danelon, F.; Mucci, M.; Franceschi, M.; Smirne, S.; Camanni, F.

Neuropsychological Heterogeneity in Mild Alzheimer's Disease 321

Binetti, G.: Magni, E.; Padovani, A.; Cappa, S.F.; Bianchetti, A.;

Trabucchi, $M$.
Epidemiology of Depressive Symptoms in Elderly Primary

Care Attenders

Evans, S.; Katona, C.

Brain Perfusion Imaging in Parkinson's Disease and

Alzheimer's Disease Demonstrated by Three-Dimensional

Surface Display with ${ }^{123}$ I-Iodoamphetamine

Tachibana, H.; Kawabata, K.; Tomino, Y.; Sugita, M., Fukuchi, M.

Age at Onset and SPECT Imaging in Alzheimer's Disease

Caffarra, P.; Scaglioni, A.; Malvezzi, L.; Previdi, P.; Spreafico, L.;

Salmaso, D.

Potential Biological Targets for Anti-Alzheimer Drugs

Allain, H.; Belliard, S.; de Certaines, J.; Bentué-Ferrer, D.; Bureau, M.;

Lacroix, $\mathrm{P}$.

Author Index

Subject Index

\section{S. Karger}

Medical and Scientific Publishers

Basel - Freiburg - Paris - London

New York · New Delhi · Bangkok

Singapore $\cdot$ Tokyo $\cdot$ Sydney

\section{Drug Dosage}

The authors and the publisher have exerted every effort to ensure that drug selection and dosage set forth in this text are in accord with current recommendations and practice at the time of publication. However, in view of ongoing research, changes in government regulations, and the constant flow of information relating to drug therapy and drug reactions, the reader is urged to check the package insert for each drug for any change in indications and dosage and for added warnings and precautions. This is particularly important when the recommended agent is a new and/or infrequently employed drug.
All rights reserved

No part of this publication may be translated into other languages, reproduced or utilized in any form or by any means. electronic or mechanical, including photocopying, recording. microcopying or by any information storage and retrieval system, without permission in writing from the publisher or, in the case of photocopying, direct payment of a specified fee to the Copyright Clearance Center (sce "Information for Readers and Subscribers')

(c) Copyright 1993 by S. Karger AG.

P.O. Box, $\mathrm{CH}-4009$ Basel (Switzerland) Printed in Switzerland on acid-free paper by Thür AG Offsetdruck, Pratteln 
Martin Dichgans ${ }^{\mathrm{a}}$

Ursula Mönninga

Gerhard Königa

Rupert Sandbrink ${ }^{\mathrm{a}}$

Colin L. Masters ${ }^{\mathrm{b}}$

Konrad Beyreuther ${ }^{\text {a }}$

a Center for Molecular Biology, University of Heidelberg, FRG;

b Department of Pathology, University of

Melbourne, Parkville, Vic., Australia

\title{
APP Expression in Primary Neuronal Cell Cultures from P6 Mice during in vitro Differentiation
}

\begin{abstract}
Primary neuronal cell cultures from P6 mice were investigated in order to study amyloid protein precursor (APP) gene expression in differentiating neurons. Cerebellar granule cells which strongly express APP 695 allowed the identification of three distinct isoforms of neuronal APP 695. The high-molecular-weight form of APP 695 is sialylated. The expression pattern of neuronal APP 695 changes during in vitro differentiation. Sialylated forms become more abundant upon longer cultivation time. The secreted forms of sialylated, neuronal APP 695 are shown to comigrate with APP isolated from cerebrospinal fluid. We suggest that the different sialylation states of APP 695 may reflect the modulation of cell-cell and cell-substrate interactions during in vitro differentiation and regeneration.
\end{abstract}

\section{Key Words
Alzheimer's
Amyloid p
Cerebellar
Sialic acid \\ Key Words
Alzheimer'
Amyloid p
Cerebellar
Sialic acid}

Amyloid protein precursor

Cerebellar neurons

\section{Introduction}

Alzheimer's disease $(\mathrm{AD})$ is a neurodegenerative disorder characterized by intracellular neurofibrillary tangles, extracellular plaques and cerebrovascular amyloid in the brains of affected individuals. The principal component of the deposits is the $\beta A 4$ protein, which is derived from a larger amyloid protein precursor (APP) [1]. Several alternative splice forms of this membrane-spanning glycoprotein have been identified so far [2-7]. As shown by different authors, APP 695 is the predominantly expressed form in the developing central nervous system, whereas peripheral tissues mainly express the KPI-containing APPs [4, 6, 8-11]. Biochemical analyses have shown that APP is posttranslationaly modified by $\mathrm{N}$ - and O-glycosylation as well as tyrosine sulfation and serine phosphory- lation $[12,13]$. Proteolytic cleavage within the amyloidogenic region leads to secretion of a large soluble $\mathrm{NH}_{2-}$ terminal APP fragment into the surrounding environment $[12,14,15]$. Such carboxyl-terminal truncated molecules are found in cerebrospinal fluid (CSF) and blood [12, 16, 17]. APPs circulating in blood are mainly derived from APP 751 and 770. They may be secreted by platelets and leukocytes and were shown to be identical with protease nexin 2 [18-21]. In contrast, soluble APP found in CSF mainly lacks the KPI insert, reflecting the predominant expression of APP 695 in the central nervous system.

It has been suggested by several authors that APP 695 plays an important role in neuronal differentiation and regeneration [22-24].

Cerebellar cells derived from early postnatal brain share many of the features characteristic for their counter- 
parts in vivo such as cell migration, axonal sprouting, synapse formation and electric activity [25-28]. Thus they provide an ideal model for investigating APP biosynthesis during differentiation processes and formation of neuronal networks. Using this approach, we have studied the biogenesis of APP in developing neurons. Our findings show that APP is indeed strongly expressed by neuronal cells. Differentiation of these cells in vitro was associated with changes in posttranslational modification of amyloid protein precursor.

\section{Materials and Methods}

\section{Cell Culture}

The cell culture protocol employed was a modification of the methods described by Schnitzer et al. [29].

Cerebelli were obtained from postnatal Balb/c mice (P6). At this stage of development, granule cells constitute approximately $90 \%$ of all cerebellar neurons [30]. After removal of the meninges, cerebelli were incubated for $15 \mathrm{~min}$ in a solution of $10 \mathrm{mg} / \mathrm{ml}$ trypsin in $\mathrm{Ca}^{2+}$. and $\mathrm{Mg}^{2+}$-containing Hanks balanced salt solution $\left(\mathrm{HBSS}^{+}\right.$). Cerebelli were rinsed three times in $\mathrm{Ca}^{2+}$ - and $\mathrm{Mg}^{2+}$-free $\mathrm{HBSS}$, followed by dissociation of the cells. This was done in $0.5 \mathrm{mg} / \mathrm{ml}$ DNAse I in HBSS $^{+}$by trituration through the narrowed bore of a fire-polished Pasteur pipette. Cells were distributed to polylysine-coated (100 $\mu \mathrm{g} /$ $\mathrm{ml}$ ) culture dishes containing $2 \mathrm{ml}$ of Earl's Basal Medium (BME; Gibco) buffered with sodium bicarbonate $(10 \mathrm{mM})$ and supplemented with $10 \%$ horse serum (Gibco). Neurons were plated at a density of about $5 \times 10^{4} \mathrm{cells} / \mathrm{cm}^{2}$. Cultures were maintained in a humified incubator at $37^{\circ} \mathrm{C}$ in $5 \% \mathrm{CO}_{2}$.

\section{Immunocytochemistry}

Coverslips were removed from culture dishes, briefly rinsed with phosphate-buffered saline (PBS; $\mathrm{pH} 7.2$ ) and fixed with freshly prepared 4\% paraformaldehyde (in PBS; $\mathrm{pH} 7.2$ ) at room temperature for $15 \mathrm{~min}$. After permeabilization with $0.3 \%$ TX-100 in PBS for 5 min, nonspecific binding sites were blocked with $1 \%$ human serum albumin, 10\% FCS in PBS for $30 \mathrm{~min}$ at room temperature (RT). Cells were then incubated with primary antibodies in PBS $(0.3 \%$ TX$100,1 \%$ human serum albumin) at $4{ }^{\circ} \mathrm{C}$ overnight, extensively washed with PBS and incubated with fluorescein- and rhodamineconjugated secondary antibodies for $1 \mathrm{~h}$ at RT. Coverslips were washed for $45 \mathrm{~min}$ in PBS before being mounted upside down on a drop of aqueous mounting medium (Moviol including 2.5\% DAB$\mathrm{CO}$ ). Cells were examined on a Zeiss axioplan microscope equipped with phase contrast and epifluorescence optics for rhodamine and fluorescein.

Antibodies were used at the following dilutions: polyclonal antiFd-APP [12], 1:400; monoclonal anti-GFAP (Serva), 1:50; monoclonal anti-neurofilament (Dakopatts), 1:50; fluorescein-conjugated goat anti-rabbit (Sigma) 1:100; rhodamine-conjugated goat antimouse (Jackson), 1:100.

\section{Biosynthetic Labeling}

After removal of the culture medium, cells were radioactively labeled with $120 \mu \mathrm{Ci}$ of $\left.{ }^{35} \mathrm{~S}\right]$ methionine (Amersham) in $1.5 \mathrm{ml}$ of methionine-free Dulbecco's modified Eagle's medium (DMEM) for $4 \mathrm{~h}$. The conditioned medium was then cleared by centrifugation and stored at $-20^{\circ} \mathrm{C}$. Cells were washed once with phosphate-buffered saline. For lysis, cells were resuspended in $0.2 \mathrm{ml}$ of lysis buffer [50 $\mathrm{m} M$ Tris, pH 7.5, $150 \mathrm{~m} M \mathrm{NaCl}, 2 \mathrm{~m} M$ EDTA, $1 \%$ Nonidet P-40, 1\% Triton X-100. $2 \mathrm{~m} M$ phenylmethanesulfonylfluoride (PMSF), $10 \mu \mathrm{g} / \mathrm{ml}$ aprotinin, $10 \mu \mathrm{g} / \mathrm{ml}$ leupeptin and $1.6 \mathrm{mg} / \mathrm{ml}$ iodoacetamide] and incubated for $30 \mathrm{~min}$ on ice. Cell lysates were centrifuged at $10,000 \mathrm{~g}$ for $5 \mathrm{~min}$, and the supernatants were stored at $-20^{\circ} \mathrm{C}$ until further use. The extraction pellet was discarded.

\section{Immunoprecipitation}

For immunoprecipitation of $\left[{ }^{35}\right.$ S] methionine-labeled APP, $100 \mu \mathrm{l}$ of cell lysate or $750 \mu \mathrm{l}$ of conditioned medium were used. The cell lysate was diluted $1: 1$ with ice-cooled washing buffer B $(20 \mathrm{~m} M$ Tris, pH 7.5, $500 \mathrm{~m} M \mathrm{NaCl}, 0.5 \%$ Nonidet P-40, $2 \mathrm{~m} M$ PMSF). Lysate was preincubated for $2 \mathrm{~h}$ at room temperature with $10 \mu \mathrm{l}$ of preimmune serum and $3 \mathrm{mg}$ of protein A-Sepharose. Insoluble complexes were spinned down and discarded. The supernatants were incubated for $1 \mathrm{~h}$ at room temperature with $5 \mu \mathrm{l}$ of undiluted anti-CT or antiFdAPP. The polyclonal anti-CT antiserum was raised against a synthetic peptide, which corresponds to the $\mathrm{COOH}$-terminal 43 residues of APP. Polyclonal anti-FdAPP antiserum was raised against purified Escherichia coli FdAPP fusion protein consisting of APP 695 and the Fd fragment of the murine IgM heavy chain [12].

After addition of $2 \mathrm{mg}$ of protein A-Sepharose, the mixture was incubated for $30 \mathrm{~min}$ at RT. Nonbound proteins were removed from Sepharose beads by sequential washing with buffer A ( $20 \mathrm{~m} M$ Tris, pH 7.5, $150 \mathrm{~m} M \mathrm{NaCl}, 0.4 \%$ Nonidet P-40, $0.4 \%$ Triton X-100, $2 \mathrm{~m} M$ PMSF), washing buffer B and finally with TSA solution (20 $\mathrm{m} M$ Tris, $\mathrm{pH} 8.0,150 \mathrm{~m} M \mathrm{NaCl}$ ). The immunoprecipitates were fractionated by SDS-PAGE (8\%). Gels were soaked in enhancer solution, dried and exposed to Kodak X-OMAT AR film at $-70^{\circ} \mathrm{C}$.

Secreted APP was precipitated under nondetergent conditions and analyzed by subsequent immunoblotting. Immunoblotting was performed as described by Mönning et al. [34].

\section{Enzymatic Digestion}

Prior to enzymatic digestion with neuraminidase from Clostridium perfringens (Sigma), immunoprecipitated proteins were denaturated in $20 \mu \mathrm{l}$ of $0.2 \% \mathrm{SDS}, 2 \% \mathrm{MCE}$ for $10 \mathrm{~min}$ at $100^{\circ} \mathrm{C}$ followed by addition of $100 \mu \mathrm{l}$ of sodium-acetate buffer $(\mathrm{pH} 6.0 ; 100 \mathrm{mM})$. Enzymatic digestion was performed with $10 \mathrm{mU}$ of neuraminidase at $37^{\circ} \mathrm{C}$ for $16 \mathrm{~h}$. The proteins were dried and resuspended in Laemmli sample buffer. After boiling, labeled proteins were subjected to SDSPAGE.

\section{Results}

\section{Immunocytochemistry}

For immunocytochemical localization of APP in primary neuronal cell culture, cerebellar cells from P6 mice were isolated and grown on poly-l-lysine-coated coverslips in the presence of $10 \%$ horse serum. Medium was not changed until cells were used for staining procedure, usually carried out after six days of cultivation. Staining 
a
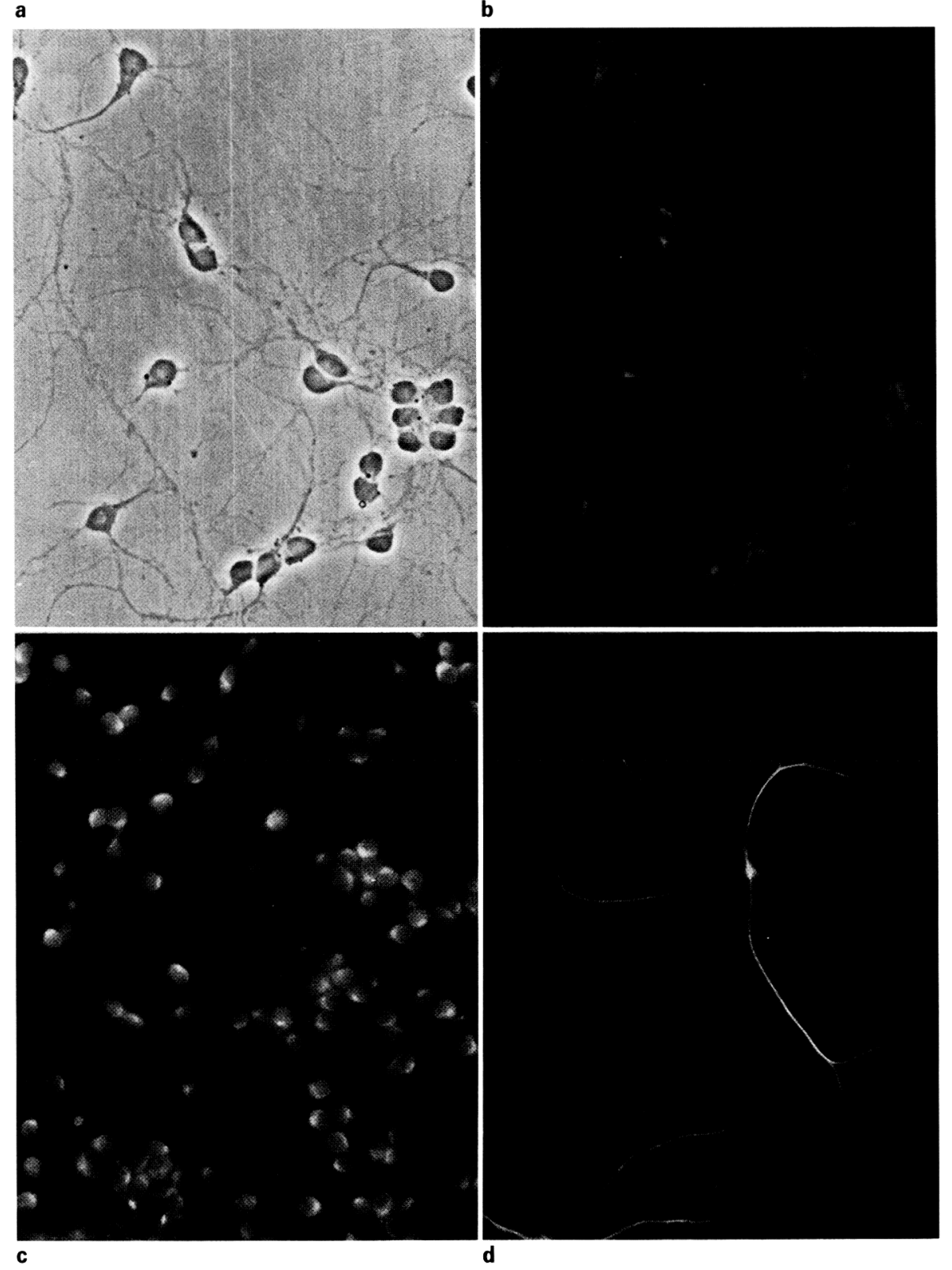

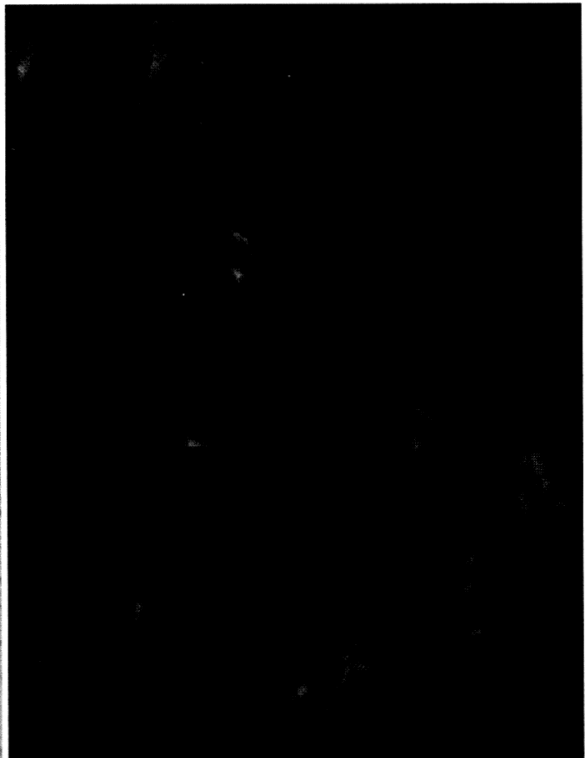

Fig. 1. Indirect immunofluorescence of primary cerebellar cell cultures. Cells were obtained from P6 mice and cultivated for 6 days. a Phase contrast. b Immunostaining with polyclonal anti-FdAPP serum. APP immunoreactivity is detected in granular cells. c/d Double staining with anti-Fd APP serum (c) and (d) monoclonal anti-GFAP (d). Neurons are the main source of APP-immunoreactivity (c). Astroglia, identified by GFAPstaining (d) show a weak APP staining.

\section{(1)}




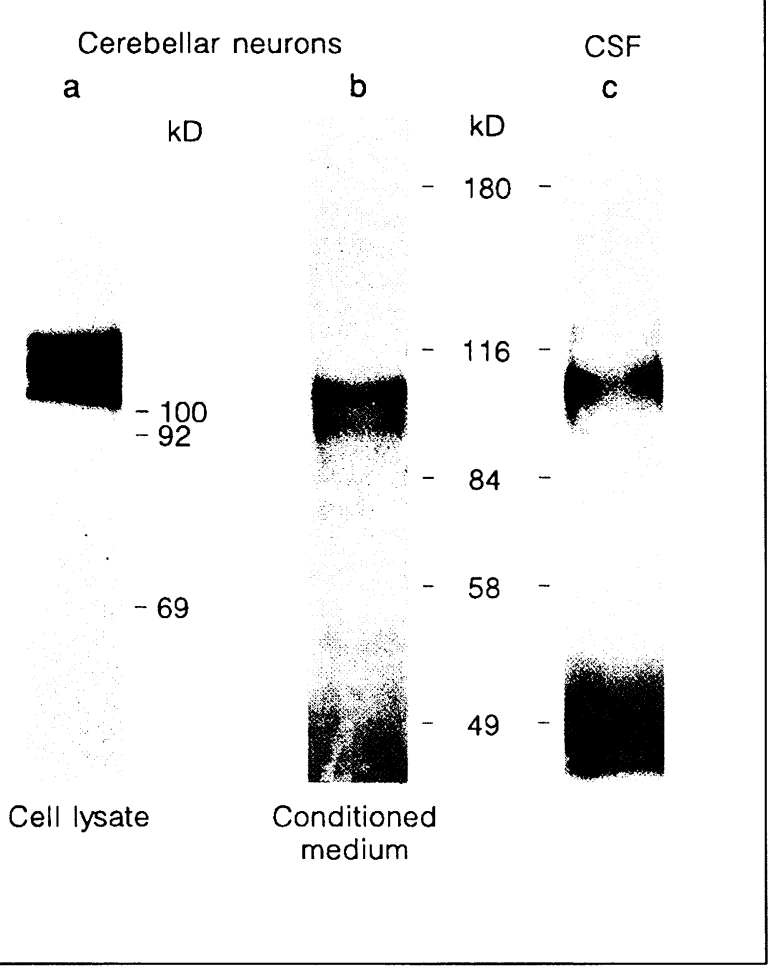

Fig. 2. Analysis of APP biosynthesis of cerebellar neurons. a Immunoprecipitation of APP from $\left[{ }^{35} \mathrm{~S}\right]$ methionine-labeled cell lysate of cerebellar neurons. Biosynthetic labeling was performed after 6 days of cultivation. The immunoprecipitates were analysed by autoradiography. Precipitation was done with the polyclonal anti-CT antiserum. b Identification of secretory APP from cerebellar neurons cultivated for 6 days. Conditioned medium of neurons was subjected to immunoprecipitation with anti-FdAPP serum. The immunoprecipitates were analyzed by immunoblotting. Detection of APP was performed with the monclonal antibody $22 \mathrm{Cl} 1$. c Western Blot analysis of APP from cerebrospinal fluid. Detection of APP was done as described in $\mathbf{b}$.

from other groups who were able to show, that APP 695 is the predominantly expressed form in neurons $[3,4,6$, $8,9,31]$.

For detection of secretory APP released by neuronal cells, conditioned medium was investigated. Since polyclonal anti-Fd APP did not precipitate soluble isoforms of mouse APP under high detergent concentrations necessary for radioactive immunoprecipitations followed by autoradiography, secretory APP was identified by Western blot analysis with monoclonal $22 \mathrm{C11}$. Two immunoreactive bands with an apparent molecular mass of 95 and $105 \mathrm{kD}$ were identified (fig. 2b). The upper band of secre- tory APP was shown to comigrate with APP derived from cerebrospinal fluid (fig. 2c).

In order to assess APP biosynthesis during differentiation, cells were cultivated for different time periods $(1,2$, 4, 6 and 9 days). At the end of each cultivation period, cells were metabolically labeled, immunoprecipitated with anti-CT and analyzed by SDS-PAGE. The autoradiography of the cell lysates is shown in figure $3 \mathrm{a}$. The densitometric scanning analysis of the autoradiography is graphically demonstrated in figure $3 \mathrm{~b}$. At all time points investigated, cells in vitro expressed all three forms of APP 695. However, within prolonged cultivation time the ratio between these different forms changed. Whereas the lower band was dominating up to $48 \mathrm{~h}$ of cultivation, the higher molecular weight APP isoforms $(112 \mathrm{kD}$ and 120 $\mathrm{kD})$ became more prominent upon longer cultivation time. At day 9 in culture, cells expressed large amounts of the high-molecular weight APP isoforms. The amount of secretory APP remained unchanged over the whole time investigated (results not shown).

\section{Posttranslational Modifications}

As could be shown by different authors, APP is posttranslationaly modified by $\mathrm{N}$ - and $\mathrm{O}$-glycosylation as well as tyrosine sulfation and serine phosphorylation [12, 13]. APP has been proposed to be a cell adhesion molecule involved in cell-cell and cell-substrate interactions [3134]. We have investigated whether neuronal APP is sialylated since sialic acid residues are known to play a key role in adhesion processes mediated by molecules like N-CAM (neuronal cell adhesion molecule) [35-37].

Immunoprecipitated APP was enzymatically digested with neuraminidase from Clostridium perfringens prior to separating proteins on SDS-PAGE. As shown in figure 4, the high molecular weight APP isoform $(120 \mathrm{kD})$ disappeared after treatment with neuraminidase. Concomitant with the decrease of cell-associated 120-kD APP isoform there was an increase in the amount of cell-associated $112-\mathrm{kD}$ APP. These experiments may indicate that the $112-\mathrm{kD}$ APP isoform is the nonsialylated precursor of the high-molecular-weight APP isoform (120 kD). Sialylation of the $112-\mathrm{kD}$ form gives rise to the apparent molecular weight shift of approximately $8 \mathrm{kD}$ resulting in highmolecular-weight APP 695.

Cell associated, sialylated APP 695 was less prominent after $24 \mathrm{~h}$ of cultivation ( $8 \%$ of total APP) but contributes to about $45 \%$ of total APP upon 9 days of in vitro cultivation. This indicates that sialylation of neuronal APP 695 is regulated in a time-dependent way during in vitro differentiation. 

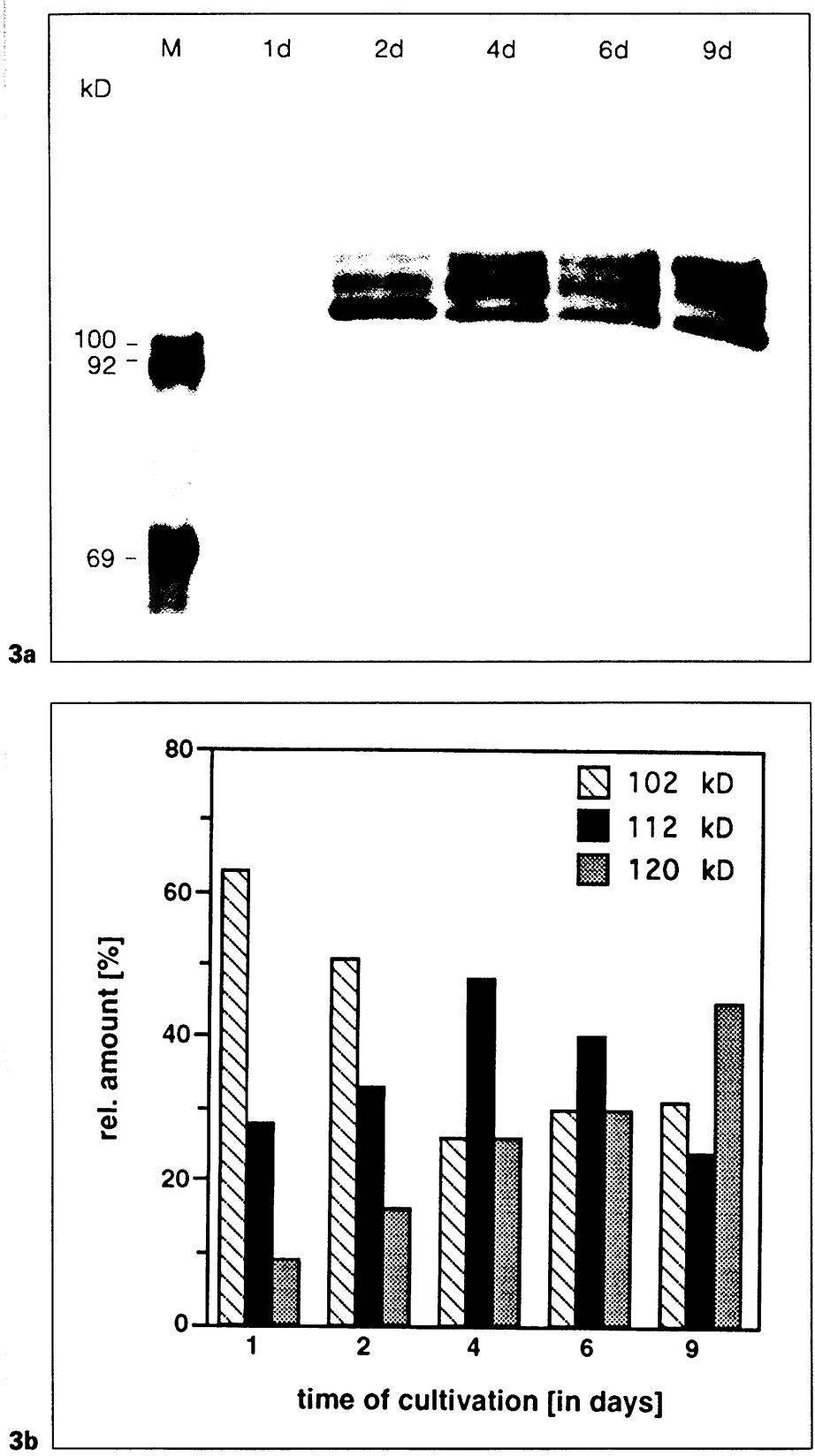

\section{Discussion}

Primary neuronal cell culture from P6 mice was investigated to gain insight into APP expression during neuronal differentiation processes. Cerebellar neurons showed an intense labeling with anti-Fd APP, whereas astrocytes revealed only a weak APP immunoreactivity. This is in agreement with results from other groups, who have shown that neurons are the main source of cerebral APP production $[10,16,31,38,39]$. Large amounts of neuro-

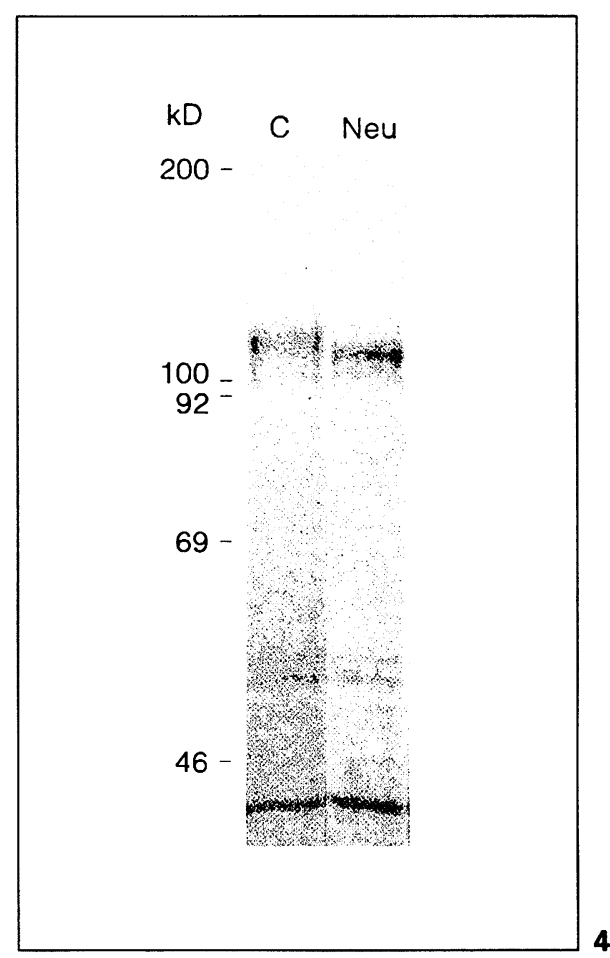

Fig. 3. Expression of APP in cerebellar neurons during in vitro differentiation. a Cells were cultivated for different time periods. Biosynthetic labeling with $\left[{ }^{35} \mathrm{~S}\right]$ methionine was done at times indicated at the top of each lane. APP was isolated from cell pellets by immunoprecipitation with anti-CT antiserum. The immunoprecipitates were analyzed as in figure $2 \mathbf{a}$. b Densitometric quantitation of the APP immunoprecipitation analysis (a) of cerebellar neurons cultivated for different time periods.

Fig. 4. Neuraminidase-treatment of cell-associated APP695 APP was immunoprecipitated from radiolabeled detergent extracts of cerebellar neurons with polyclonal anti-CT serum prior to enzymatic digestion with neuraminidase from Clostridium perfringens (Neu). Precipitates were analyzed by SDS-PAGE ( $8 \%$ ) followed by autoradiography (C, non-digested APP).

nal APP are associated with the Golgi apparatus as revealed by light- and electron-microscopic immunocytochemical techniques [39, 40]. Our data support these results since neuronal APP immunoreactivity was intracellularly located proximal to the nucleus. Rapid turnover of transmembrane APP by cleavage within the $\beta A 4$ sequence might explain the weak cell surface staining. This is evidenced by the fact that large amounts of secretory APP could be detected already on day 1 in vitro. 
We have shown that APP 695 from cerebellar neurons is posttranslationally modified by sialylation. Sialic acid residues are known to have great influence on adhesion properties of cell surface molecules. The best studied example is N-CAM (neuronal cell adhesion molecule) which exists in a highly sialylated form as well as several isoforms containing less sialic acid [41, 42]. The sialylation of N-CAM is developmentally regulated [43]. Polysialylation of N-CAM is known to promote axonal branching and decrease cell adhesivity, whereas removal of polysialic acid increases axonal fasciculation [35-37].

APP was shown to be involved in cell-cell and cell-substrate interactions [31-34]. We therefore suggest that sialylation of APP 695 might be a mechanism by which neuronal cell adhesion properties are modulated. Three distinct forms of neuronal APP 695 can be identified by Western blot analysis. The $120-\mathrm{kD}$ APP isoform was shown to be sialylated. During in vitro differentiation, changes in the expression pattern of neuronal APP 695 were observed. Sialylated APP was rarely detectable after cultivation for $24 \mathrm{~h}$, but was increased up to $45 \%$ of total APP upon 9 days of cultivation. These changes could provide the basis for regulation of cell-cell and cell-substrate interactions during in vitro differentiation of cerebellar neurons. The sialylation state seems to depend upon the state of differentiation of the neurons investigated. The presence of polysialylated cell associated APP may be a requirement for axonal branching and cell migration whereas a low sialylation state may be necessary for axonal fasciculation and cell adhesion.

We postulate that changes in the sialylation state of APP 695 play an important role in cellular interactions associated with neuronal cell migration and axonal guiding during early postnatal brain development. APP could thus belong to the group of cell surface molecules which are involved in the establishment of the neuronal network.

\section{Acknowledgements}

This work was supported by funds from the National Health and Medical Research Council, the Victorian Health Promotion Foundation, the Aluminium Development Corporation (to C.L.M.), the Cusanuswerk (to M.D.) and the Deutsche Forschungsgemeinschaft and the Bundesministerium für Forschung und Technologie (to K.B.)

\section{References}

1 Kang J, Lemaire H-G, Unterbeck A, Salbaum JM, Masters CL, Grzeschik K-H, Multhaup G, Beyreuther K, Mueller-Hill B: The precursor of Alzheimer's disease amyloid $\beta A 4$ protein resembles a cell-surface receptor. Nature 1987; 325:733-736.

2 Ponte P, Gonzalez-De Whitt P, Schilling J, Miller J, Hsu D, Greenberg B, Davis K, Wallace W, Lieberburg I, Fuller F, Cordell B: A new A4 amyloid mRNA contains a domain homologous to serine protease inhibitors. Nature 1988;311:525-527.

3 Tanzi RE, McClatchey AI, Lamperti ED, VillaKomaroff L, Gusella GF, Neve RL: Protease inhibitor domain encoded by an amyloid protein precursor mRNA associated with Alzheimer's disease. Nature 1988;311:528-530.

4 Kitaguchi N, Takahashi Y, Tokushima Y, Shiojiri S, Ito H: Novel precursor of Alzheimer's disease amyloid protein shows protease inhibitor activity. Nature 1988;331:530-532.

5 de Sauvage F, Octave JN: A novel mRNA of the A4 amyloid precursor gene coding for a possible secreted protein. Science 1989;245: 651-653.
6 Golde TE, Estus S, Usiak M, Younkin LH, Younkin SG: Expression of $\beta$-amyloid protein precursor mRNA's: Recognition of a novel alternatively spliced form and quantitation in Alzheimer's disease using PCR. Neuron 1990; 4:235-267.

7 König G, Mönning U, Czech C, Prior R, Banati $R$, Schreiter-Gasser U, Bauer J, Masters CL, Beyreuther K: Identification and differential expression of novel alternative splice isoform and the $\beta \mathrm{A} 4$ amyloid precursor protein (APP) mRNA in leukocytes and brain microglial cells. J Biol Chem 1992;267:10804-10809.

8 König G, Salbaum JM, Wiestler O, Lang W, Schmitt HP, Masters CL, Beyreuther K: Alternative splicing of the $\beta A 4$ amyloid gene of Alzheimer's disease in cortex of control and Alzheimer's disease patients. Mol Brain Res 1991; 9:259-262.

9 Koo EH, Sisodia SS, Cork LC, Unterbeck A, Bayne RM, Price DL: Differential expression of amyloid precursor protein mRNA's in cases of Alzheimer's disease and in aged nonhuman primates. Neuron 1990;2:97-104.

10 LeBlanc AC, Chen HY, Autilio-Gambetti L, Gambetti P: Differential APP gene expression in rat cerebal cortex, meninges, and primary astroglial, microglial and neuronal cultures. FEBS 1991;292:171-178.
11 Löffler J, Huber G: $\beta$-Amyloid precursor protein isoforms in various rat brain regions and during brain development. J Neurochem 1992; 59(4):1316-1324.

12 Weidemann A, König G, Bunke D, Fischer P, Salbaum JM, Masters CL, Beyreuther K: Identification, biogenesis, and localization of precursors of Alzheimer's disease A4 amyloid protein. Cell 1989;57:115-126.

13 Suzuki T, Najrn AC, Gandy SE, Greengard, P.: Phosphorylation of Alzheimer amyloid precursor by protein kinase C, Neuroscience 1992;48: 755-761.

14 Sisodia SS, Koo EH, Beyreuther K, Unterbeck A, Price DL: Evidence that $\beta$-amyloid protein in Alzheimer's disease is not derived by normal processing. Science 1990;248:492-495.

15 Esch FS, Keim PS, Beattle EC, Blacher RW, Culwell AR, Oltersdorf T, McClure D, Ward PJ: Cleavage of amyloid $\beta$ peptide during constitutive processing of its precursor. Science 1990;248:1122-1124.

16 Palmert MR, Podlisny MB, Witker DS, Oltersdorf T, Younkin LH, Selkoe DJ, Younkin SG: The $\beta$-amyloid protein precursor of Alzheimer disease has soluble derivatives found in human brain and in cerebrospinal fluid. Proc Natl Acad Sci USA 1989;86:6338-6342. 
17 Podlisny MB, Mammen AL, Schlossmacher MG, Palmert MR, Younkin SG, Selkoe DJ: Detection of soluble forms of the $\beta$-amyloid precursor protein in human plasma. Biochem Biophys Res Commun 1990;167:1094-1101.

18 Smith RP, Darryl A, Higuchi GJ, Broze JR: Platelet coagulation factor XIa-inhibitor, a form of Alzheimer amyloid precursor protein. Science 1990;248:1126-1128.

19 Mönning U, König G, Prior R, Mechler H, Schreiter-Gasser U, Masters CL, Beyreuther K: Synthesis and secretion of Alzheimer amyloid $\beta A 4$ precursor protein by stimulated human peripheral blood leukocytes. FEBS 1990;277: 261-266.

20 Oltersdorf T, Fritz LC, Schenk DB, Lieberburg I, Johnson-Wood KL, Beattie EC, Ward PJ, Blacher RW, Dovey HF, Sinha S: The secreted form of the Alzheimer's amyloid precursor protein with the Kunitz domain is protease nexinII. Nature 1989;341:144-147.

21 van Nostrand WE, Wagner SL, Suzuki M, Choi $\mathrm{BH}$, Farrow JS, Geddes JW, Cotman CW, Cunningham DD: Protease nexin II, a potent antichymotrypsin, shows identity to amyloid $\beta$ protein precursor. Nature 1989;341:546-549.

22 König G, Masters CL, Beyreuther K: Retinoic acid induced differential neuroblastoma cells show increased expression of the $\beta A 4$ amyloid gene of Alzheimer's disease and an altered splicing pattern. FEBS Lett 1990;269:305310.

23 Scott JN, Parhad IM, Clark AW: $\beta$-Amyloid precursor protein gene is differentially expressed in axotomized sensory and motor systems. Mol Brain Res 1991;10:315-325.

24 Milward EA, Papadopoulos R, Fuller SJ, Moir RD, Small D, Beyreuther K, Masters CL: The amyliod protein precursor in Alzheimer's disease is a mediator of the effects of nerve growth factor on nerve outgrowth. Neuron 1992;9: 129-137.
25 Rakic P: Neuron-Glia relationship during granular cell migration in developing cerebellar cortex: A Golgi and electron microscopic study in Macacus rhesus. J Comp Neurol 1971;141: 283-312.

26 Trenkner E, Smith D, Segil N: Is cerebellar granule cell migration regulated by an internal clock? J Neurosci 1984;4:2850-2855.

27 Edmondson JC, Hatten ME: Glial-guided granule neuron migrating in vitro: A high resolution time-lapse video microscopic study. J Neurosci 1987;7:1928-1934.

28 Hockberger PE, Tseng H-Y, Connor JA: Development of rat cerebellar Purkinje cells: Electrophysiological properties following acute isolation and in long term culture. J Neurosci 1989; 9:2258-2271.

29 Schnitzer J, Schachner M: Expression of Thy-1, $\mathrm{H}-2$, and NS-4 cell surface antigens and tetanus toxin receptors in early postnatal and adult mouse cerebellum. J Neuroimmunol 1981;1: 429-456.

30 Hatten ME: Neuronal regulation of astroglial morphology and proliferation in vivo. $\mathrm{J}$ Cell Biol 1985;100:384-396.

31 Shivers BD, Hilbich C, Multhaup G, Salbaum M, Beyreuther K, Seeburg P: Alzheimer's disease amyloidogenic glycoprotein: Expression pattern in rat brain suggests a role in cell contact. EMBO J 1988;7:1365-1370.

32 Schubert D, Saitoh T, Cole G: The regulatory role of amyloid $\beta$ protein precursor secretion and its modulatory role in cell adhesion. Neuron 1989;3:689-694.

33 Breen KC, Bruce M, Anderton BH: Beta amyloid precursor protein mediates neuronal cellcell and cell-surface adhesion. J Neurosci Res 1991;28:90-100.

34 Mönning U, König G. Banati RB, Mechler H, Czech C, Gehrmann J, Schreiter-Gasser U, Masters CL, Beyreuther K: Alzheimer $\beta A 4$ amyloid protein precursor in immunocompetent cells. J Biol Chem 1992;267:2395023956.
35 Doherty P, Cohen J, Walsh FS: Neurite outgrowth in response to transfected N-CAM changes during development and is modulated by polysialic acid. Neuron 1990;5:209-219.

36 Hoffman S, Edelman GM: Kinetics of homophilic binding by embryonic and adult forms of the neural cell adhesion molecule. Proc Natl Acad Sci USA 1983;80:5762-5766.

37 Landmesser L, Dahm L, Tang J, Rutishauser $\mathrm{U}$ : Polysialic acid as a regulator of intramuscular nerve branching during embryonic development. Neuron 1990;4:655-667.

38 Card JP, Meade RP, Davis LG: Immunocytochemical localization of the precursor protein for $\beta$-amyloid in the rat central nervous system. Neuron 1988:1:835-846.

39 Schubert M, Prior R, Weidemann A, Dircksen $\mathrm{H}$, Multhaup $\mathrm{G}$, Masters $\mathrm{CL}$, Beyreuther $\mathrm{K}$ : Localization of Alzeimer $\beta A 4$ amyloid precursor protein at central and peripheral synaptic sites. Brain Res 1991;563:184-194.

40 Palacios G, Palacios JM, Mengod G, Frey P: Beta amyloid precursor protein localization in the Golgi apparatus in neurons and oligodendrocytes: An immunocytochemical, structural and ultrastructural study in normal and axotomized neurons. Mol Brain Res 1992;15:195206.

41 Hoffman S, Sorkin BC, White PC, Brackenbury R, Mailhammer R, Rutishauser U, Cunningham B, Edelman GM: Chemical characterization of neural cell adhesion molecule purified from embryonic brain membranes. J Biol Chem 1982;257:7720-7729.

42 Rothbard JB, Brackenbury R, Cunningham BA, Edelman GM: Difference in the carbohydrate structures of neural cell-adhesion molecules from adult and embryonic chicken brains. J Biol Chem 1982;257:1 1064-11069.

43 Edelman GM, Chuong C-M: Embryonic to adult conversion of neuronal cell adhesion molecules in normal and staggerer mice. Proc Natl Acad Sci USA 1982;79:7036-7040. 